ISSN 0103-9954

\title{
MORPHOLOGICAL AND GENETIC ANALYSIS OF Triplaris guayaquilensis Wedd (POLYGONACEAE): ONE NATIVE TREE OF ECUADOR
}

\author{
ANÁLISIS MORFOLÓGICO Y GENÉTICO DE Triplaris guayaquilensis Wedd (POLYGONACEAE): \\ UN ÁRBOL NATIVO DE ECUADOR
}

\author{
José Enrique Nieto-Rodríguez ${ }^{1}$ Sanjuana Hernández-Delgado ${ }^{2}$ Netzahualcoyotl Mayek-Pérez ${ }^{3}$
}

\begin{abstract}
In this paper, we assessed six native populations (55 trees) of Triplaris guayaquilensis Wedd (Fernan Sanchez), one of the major forest species from Ecuador, using morphological and AFLP (Amplified Fragment Length Polymorphisms) data. The populations were collected through two macro-sites (Central coastals: Quevedo, Ventanas, la Guayas; Andean surroundings: la Maná, Patricia Pilar, Pichincha). The populations showed the following traits: straight shaft (66\%); round, irregular top shape (50\%); and branch insertion angle $0^{\circ}-30^{\circ}(86 \%)$. Four qualitative (straight shape, type of leaf edge, leaf width and leaf pubescence) and four quantitative (commercial tree height, basal area, commercial volume and total volume) traits were the most explicative traits present after Principal Component Analysis (PCA). PCA separated populations into two groups: one group included populations from Central Coastals which showed morphological traits highly and positively correlated with wood production, and the other group included populations with lower tree growth from the Andean surroundings. Populations from Central Coastals showed the highest values of genetic diversity indexes, AFLP markers separated populations based on the macro site of origin. For $K$ $=2$ Bayesian analysis separated FS populations into two groups; two populations from Central Coastals region and the other four the Andean surroundings region (3) and 1 from Central Coastals (La Guayas). For greater $K$ values, the genetic fragmentation of populations by origins was evident since for $K=5$ four groups were performed: one including populations from Quevedo and Ventanas and other from La Guayas (Coastals), the third group included trees from La Mana and Pichincha and the fourth, from Patricia Pilar (Andean surroundings). Results suggested the constant and effective genetic recombination or the genetic flow among and within Fernan Sanchez populations with a clear tendency towards genetic differentiation.
\end{abstract}

Keywords: Fernan Sanchez; forest genetic resources; genetic variability; molecular markers.

\section{RESUMEN}

En éste trabajo, seis poblaciones nativas (55 árboles) de Triplaris guayaquilensis Wedd (Fernán Sánchez), una de las principales species forestales de Ecuador, se sometieron al análisis morfológico y genético con AFLPs (polimorfismos en la longitud de los fragmentos amplificados). Las poblaciones se colectaron a través de dos macro-sitios (Litoral Central: Quevedo, Ventanas, la Guayas; Estribaciones de los Andes: la Maná, Patricia Pilar, Pichincha). Las poblaciones exhibieron las siguientes características: fuste recto (66 \%); forma de la copa irregular y redonda (50\%); ángulo de inserción de las ramas de $0^{\circ}$ a $30^{\circ}$ (86\%). Cuatro características cualitativas (forma del fuste, tipo de terminación de hojas, ancho de hojas y

1. Forest Engineer. MSc. in Biotechnology, Dr. Sci. student of the Centro de Investigación en Ciencia Aplicada y Tecnología Avanzada (CICATA) Unidad Altamira, Instituto Politécnico Nacional, Km 14.5, Carretera Tampico-Puerto Industrial Altamira, 89600, Altamira, México, Professor of Unidad de Investigación Científica y Tecnológica de la Universidad Técnica Estatal de Quevedo, Av. Quito km 1 1², 0073, Quevedo, Los Ríos, Ecuador. hnieto77@hotmail.com

2. Food Engineer. MSc. In Biotechnology. Professor, Centro de Biotecnología Genómica, Instituto Politécnico Nacional, Blvd. del Maestro, s/n esq. Elias Piña, Col. Narciso Mendoza, 88710, Reynosa, México. shernandezd@ipn.mx

3. Agronomic Engineer, MSc. and Dr. Sci. in Genetics, Professor Centro de Biotecnología Genómica, Instituto Politécnico Nacional, Blvd. del Maestro, s/n esq. Elias Piña, Col. Narciso Mendoza, 88710, Reynosa, México. nmayek@ipn.mx

Recebido para publicação em 15/06/2011 e aceito em 21/11/2011 
pubescencia de las hojas) y cuatro cuantitativas (altura comercial del árbol, área basal, volumen comercial y volumen total) fueron las más explicativas de acuerdo con el análisis de componentes principales (ACP). El ACP separó las poblaciones en dos grupos: uno incluyó poblaciones del Litoral Central, con características morfológicas alta y positivamente correlacionadas con la producción de madera y, el otro, con poblaciones con crecimiento de árboles menor provenientes de las estribaciones de los Andes. Las poblaciones del Litoral Central mostraron los mayores valores de diversidad genetic y los marcadores AFLP separaron dichas poblaciones con base en el macrositio de origen. Para un valor $K=2$ el análisis Bayesiano separó las poblaciones de FS en dos grupos: dos poblaciones de la región Litoral Central y las otras cuatro de la región de las estribaciones de los Andes (3) y una del Litoral Central (La Guayas). Para valores $K$ mayores fue evidente la fragmentación genética de las poblaciones de acuerdo con el origen pues para $K=5$ se formaron cuatro grupos: uno incluyó poblaciones de Quevedo y Ventanas y otro de La Guayas (Litoral), un tercer grupo incluyó árboles de La Mana y Pichincha y un cuarto grupo, de Patricia Pilar (estribaciones de los Andes). Los resultados sugieren la constante y efectiva recombinación genética o flujo genetic entre y dentro de poblaciones de Fernán Sánchez con una tendencia clara hacia la diferenciación genética.

Palabras clave: Fernán Sánchez; recursos genéticos forestales; variabilidad genética; marcadores moleculares.

\section{INTRODUCTION}

Ecuador has native resources with high productive potential for several purposes. Among the forest genetic resources outstands Triplaris guayaquilensis Wedd commonly known as Fernán Sánchez (FS), is exceptional (LITTLE and DIXON, 1969). FS is a forest species that belongs to Polygonaceae, and it is native of Ecuador where it is well distributed throughout coastal regions and near the Andes. FS shows fast vegetative growth, and it is highly demanded for the construction, agroforestry and furniture industries.

The coastal region of Ecuador is one of the more endangered regions in terms of biological diversity due deforestation and advancement of agriculture despite conservation strategies, such as the establishment of biological reservations and protected areas. Highly valuable woody species, such as Clorophora tinctoria, Cordia machranta, Tectona grandis and Triplaris guayaquilensis, have been indiscriminately used. Currently, original forestry populations are poor and have a risk of genetic erosion. Throughout the coastal region, forests and agriculture farms coexist (VALVERDE, 1991). Little knowledge has been gathered about Triplaris with the exception of botanical and biological studies (JORGESEN and LEON, 1999). Several studies have promoted a slow advancement of botanical, genetic and molecular analyses of native populations in Ecuador (AGUIRRE and LARS, 2005).

Some advances have been obtained in the genetic analyses of major forest resources of Ecuador, such as Schizolobium parahybum (CANCHIGNIAMARTINEZ et al., 2007) and Tectona grandis
(NIETO-RODRIGUEZ, 2010), where molecular marker strategies have been successfully used to analyze genetic relationships among and within native populations. In addition to the improved knowledge of genetic diversity patterns and population genetics, the identification of promising trees should increase the potential of breeding and seed production of major forest resources (NAMKOOG and KOSHY, 2001) and optimize conservation. In this study, we analyzed Triplaris guayaquilensis native populations from two macro sites of Ecuador to determine the genetic relationships among and within populations based on morphological and genetic markers.

\section{MATERIALS AND METHODS}

\section{Germplasm}

Young leaves of each-one of 55 trees from six Fernan Sanchez (FS) populations were collected through two macro-sites of Ecuador (Table 1). One macro-site (Central Coastal) includes populations from Quevedo, Ventanas and Guayas with tropical, humid forest conditions (bh-T). The other macrosite (Andean surroundings) includes plants from La Mana, Pichincha and Patricia Pilar, and these regions have tropical, humid and warm forest conditions (bh-PMtc) (HOLDRIGE, 1977; CAÑADAS et al., 1986, VALLEJO and MALDONADO, 1987). In each site, geographical (latitude, longitude and altitude) and weather data were recorded. Seed collection, manipulation, and storage were conducted as previously described by ORDOÑEZ et al. (2005) for conservation in one local germplasm bank of the 'Universidad Técnica Estatal de Quevedo', 
Quevedo, in Ecuador. In each site of collection trees is naturally growing and they were randomly choosen taking care that all trees were representative of each population and similar height and age; the minimum distance between trees was $8 \mathrm{~m}$ and maximum of $50 \mathrm{~m}$. The size of surface in each forest was variable ( $1-3 \mathrm{ha})$.

\section{Morphological analysis}

FS plants were morphologically analyzed based on descriptors for tropical woody species as previously described by LEOPOLD et al. (2001) and modified by ORDÓÑEZ et al. (2005) (Table 2). For this study, 16 qualitative traits and 6 quantitative traits were registered as follows: 11 traits corresponded to tree timber, 2 traits to top tree, and 9 to leaves.

\section{Genetic analysis}

Genomic DNA was isolated and purified from $100 \mathrm{mg}$ of fresh young leaves from each plant/ tree using a DNeasy ${ }^{\circledR}$ Plant Mini kit $\left(\right.$ Qiagen $\left.{ }^{\circledR}\right)$. Samples were stored at $4{ }^{\circ} \mathrm{C}$. The AFLP procedure was performed as previously described by VOS et al. (1995). Approximately $200 \mathrm{ng}$ of genomic DNA was digested with $50 \mathrm{U}$ of EcoRI and $15 \mathrm{U}$ of Tru 91 endonucleases at $37^{\circ} \mathrm{C}$ for 210 min followed by incubation at $70{ }^{\circ} \mathrm{C}$ for $15 \mathrm{~min}$ in a thermocycler (Gene Amp 9700, Applied Biosystems). The DNA fragments were linked to EcoRI and MseI adapters (EcoRI adapter, 5'-CTCGTAGACTGCGTACC3'/3'CTGACGCATGGTTAA-5'; and MseI adapter, 5'-GACGATGAGTCCTGAG-3'/3'TACTCAGGACTCAT-5') at $20^{\circ} \mathrm{C}$ for $2 \mathrm{~h}$. After preselective amplification by PCR using nucleo-

TABLE 1: Geographical origin of Triplaris guayaquilensis populations from Ecuador.

TABLA 1: Origen geográfico de poblaciones de Triplaris guayaquilensis de Ecuador.

\begin{tabular}{|c|c|c|c|c|c|}
\hline \multirow[b]{2}{*}{ Location } & \multirow[b]{2}{*}{ n. } & \multicolumn{3}{|c|}{ Geographical origin } & \multirow[b]{2}{*}{ Climatic conditions } \\
\hline & & $\begin{array}{l}\text { South } \\
\text { latitude }\end{array}$ & $\begin{array}{c}\text { West } \\
\text { longitude }\end{array}$ & $\begin{array}{c}\text { Altitude } \\
\text { (masl) }\end{array}$ & \\
\hline & \multicolumn{5}{|c|}{ Macro-site: Central Coastals } \\
\hline La Guayas & 10 & $01^{\circ} 27^{\prime}$ & $79^{\circ} 08^{\prime}$ & 54 & $\begin{array}{c}\text { Dryland-tropical forest with } 16-32{ }^{\circ} \mathrm{C} \text { of } \\
\text { mean temperature and }>1000 \mathrm{~mm} \text { of annual } \\
\text { precipitation; clayish-loam soils with neutral } \mathrm{pH} \\
\text { and sedimentary origin. }\end{array}$ \\
\hline Quevedo & 9 & $01^{\circ} 05^{\prime}$ & $79^{\circ} 04^{\prime}$ & 74 & $\begin{array}{l}\text { Sub-humid tropical forest with } 23-32{ }^{\circ} \mathrm{C} \text { of } \\
\text { mean temperature and }>1500 \mathrm{~mm} \text { of annual } \\
\text { precipitation; silt-loam or sandy-loam soils with } \\
\text { slightly acid-neutral pH and volcanic origin. }\end{array}$ \\
\hline Ventanas & 8 & $01^{\circ} 25^{\prime}$ & $79^{\circ} 27^{\prime}$ & 60 & $\begin{array}{l}\text { Sub-humid tropical forest with } 23-32{ }^{\circ} \mathrm{C} \text { of } \\
\text { mean temperature and }>1500 \mathrm{~mm} \text { of annual } \\
\text { precipitation; sandy-clay soils with neutral- } \\
\text { slighlty alkaline pH and sedimentary origin. }\end{array}$ \\
\hline & \multicolumn{5}{|c|}{ Macro-site: Andean surroundings } \\
\hline Patricia Pilar & 8 & $0^{\circ} 02^{\prime}$ & $79^{\circ} 02^{\prime}$ & 90 & $\begin{array}{c}\text { Sub-humid tropical forest with } 23-28{ }^{\circ} \mathrm{C} \text { of } \\
\text { mean temperature and }>1500 \mathrm{~mm} \text { of annual } \\
\text { precipitation; loam or silt-loam soils with acid pH } \\
\text { and volcanic origin. }\end{array}$ \\
\hline La Mana & 10 & $0^{\circ} 56^{\prime}$ & $79^{\circ} 13^{\prime}$ & 315 & $\begin{array}{l}\text { Highly-humid tropical forest with } 18-30^{\circ} \mathrm{C} \\
\text { of mean temperature and }>2000 \mathrm{~mm} \text { of annual } \\
\text { precipitation; loam or silt-loam soils with acid } \mathrm{pH} \\
\text { and volcanic origin. }\end{array}$ \\
\hline Pichincha & 10 & $1^{\circ} 04^{\prime}$ & $79^{\circ} 08^{\prime}$ & 57 & $\begin{array}{l}\text { Humid tropical forest with } 12-26^{\circ} \mathrm{C} \text { of } \\
\text { mean temperature and }>2000 \mathrm{~mm} \text { of annual } \\
\text { precipitation; loam or silt-loam soils with acid } \mathrm{pH} \\
\text { and volcanic origin. }\end{array}$ \\
\hline
\end{tabular}


TABLE 2: Morphologic traits measured in Triplaris guayaquilensis from Ecuador. TABLA 2: Características morfológicas medidas en Triplaris guayaquilensis de Ecuador.

\begin{tabular}{|c|c|c|}
\hline Tree Organ & Traits & Classes/Scales \\
\hline \multirow[t]{11}{*}{ Shaft } & Shaft shape & Straight (1), curved (2), very curved (3) \\
\hline & Height of bifurcation & $1 / 3$ upper (1), $1 / 3$ middle (2), $1 / 3$ bottom ( 3 ) \\
\hline & Principal axis dominance & Total (1), partial (2), null (3) \\
\hline & Branch insertion angle & 0 to $30^{\circ}(1), 30$ to $60^{\circ}(2), 60$ to $90^{\circ}(3)$ \\
\hline & Un-bark degree & $\operatorname{High}(1)$, low $(2)$ \\
\hline & Shaft diameter to the breast height & $\mathrm{cm}$ \\
\hline & Total height & $\mathrm{m}$ \\
\hline & Commercial height & $\mathrm{m}$ \\
\hline & Trunk base area & $\mathrm{m}^{2}$ \\
\hline & Shaft total volume & $\mathrm{m}^{3}$ \\
\hline & Shaft commercial volume & $\mathrm{m}^{3}$ \\
\hline \multirow[t]{2}{*}{ Crown } & Crown diameter & $>10 \mathrm{~m}(1), 10$ to $5 \mathrm{~m}(2),<5 \mathrm{~m} \mathrm{(3)}$ \\
\hline & Crown shape & $\begin{array}{c}\text { Round (1), round-irregular (2), ovoid (3), } \\
\text { enlarged (4) }\end{array}$ \\
\hline \multirow[t]{9}{*}{ Leaf } & Edge shape & Serrated (1), undulating (2), smooth (3) \\
\hline & Adaxial color & Light green (1), Dark green (2) \\
\hline & Abaxial color & Light green (1), Dark green (2) \\
\hline & Pubescence & Present (1), absent (2) \\
\hline & Leaf length & Large (1), medium (2), small (3) \\
\hline & Leaf shape & Round (1), enlarged (2), ovoid (3) \\
\hline & Leaf width & Wide (1), narrow (2) \\
\hline & Leaf texture & Smooth (1), rough (2) \\
\hline & Venation pattern & Close to the edge (1), dispersed (2) \\
\hline
\end{tabular}

tide A, a selective amplification by PCR was performed with four combinations of EcoRI +3 and MseI +3 primers with the following PCR specifications: $94{ }^{\circ} \mathrm{C}$ for $30 \mathrm{~s} ; 20$ cycles of $56{ }^{\circ} \mathrm{C}$ for $60 \mathrm{~s}$ and $72{ }^{\circ} \mathrm{C}$ for $60 \mathrm{~s}$ (pre-amplification); $94^{\circ} \mathrm{C}$ for $30 \mathrm{~s} ; 6$ cycles of $56^{\circ} \mathrm{C}$ for $30 \mathrm{~s}$ and $72{ }^{\circ} \mathrm{C}$ for $60 \mathrm{~s} ; 94{ }^{\circ} \mathrm{C}$ for $30 \mathrm{~s}$; and 23 cycles of $56{ }^{\circ} \mathrm{C}$ for $30 \mathrm{~s}$ and $72{ }^{\circ} \mathrm{C}$ for $60 \mathrm{~s}$ (selective amplifications). Amplifications used the EcoRI +3 oligonucleotide (5'-GACTGCGTACCAATTC/NNN-3'), which was marked with IRDye ${ }^{\mathrm{TM}}-800$, and the MseI + 3 oligonucleotide (5'-GATGAGTCCTGAGTAA/ NNN-3'). Amplified products were stored at $-20{ }^{\circ} \mathrm{C}$ until use. Amplified fragments were electrophoresed in an automate sequencer IR $^{2}$ (model 4200-02G, LICOR, Lincoln, NE). Acrylamide gels were prepared according to the AFLP LI-COR Bioscience's manual. AFLP data were collected in real-time from the sequencer.

\section{Data analysis}

The mean, variance, rank, standard deviation and coefficient of variation of each morphological trait were calculated using 'Statistica' version 5 for Windows (STATSOFT, 2004). The frequencies of predetermined classes of qualitative data were also calculated.The data were subjected to principal component analysis (PCA). We then used the most explicative variables to perform a cluster analysis by estimating Nei distances and a dendrogram was constructed based on UPGMA (HAIR et al., 1992) using 'Statistica'. AFLP bands were visually numerated according their migration on a gel and we assigned the number one to the band with the highest molecular weight and so on to the band with the lowest molecular weight. We assumed that two bands with the same molecular weight in different individuals or plants as identical. We denoted the presence of one band with the number one and 
we denoted the absence of a band with zero. Binary matrices of ones and zeros were used to estimate similarity coefficients (NEI and LI, 1979), and the genetic distances among plants and populations were then calculated. Genetic distance matrices were used to construct one dendrogram based on the UPGMA algorithm (NEI and KUMAR, 2000) and the FreeTree software (HAMPL et al., 2001). Cluster analysis was corroborated by bootstrap analysis using 1,000 permutations, and the consensus dendrogram was obtained with TreeView version 1.6.6 (PAGE, 2000). In addition, we estimated the diversity indexes based on the formula previously described by POWELL et al. (1996), and we also estimated the percentage of polymorphic loci (IP) \pm standard errors per population taking into account the four AFLP primer combinations using Excel 2000. We used the IP instead of the Nei index (NEI, 1972), which has been previously reported for cedar $C$. odorata (GILLES et al., 1997; CAVERS et al., 2003; DE LA TORRE et al., 2008), pine Pinus sp. (THOMAS et al., 1999; DÍAZ et al., 2001) and mahogany S. macrophyla (LOWE et al. 2003), because IP measures the degree of polymorphism in the population whereas the Nei index measures the heterozygosity of individuals. It is important to note that one dominant marker system, such as AFLP, is not capable to directly measure heterozygosity. Similarity matrices were used to calculate the hierarchical analysis of molecular variance (AMOVA) (EXCOFFIER et al., 2005) as previously described by HUFF et al. (1993) using Arlequin 2.0 (SCHNEIDER et al., 1997). The hierarchies were macro-sites, populations, and accessions. The population genetic structure was inferred by Bayesian clustering model implemented by STRUCTURE version 2.3.1 (PRITCHARD et al., 2000) using AFLP data. To run the program, a number of genetic clusters $(K)$ characterized by the matrices of allele frequencies was first assumed. For each individual, the proportion of its genome derived from each genetic cluster (proportion of ancestry) was then estimated. Seven independent runs for each value of $K$ ranging from 1 to 6 were performed using 30,000 Markov Chain Monte Carlo repetitions and 300,000 burn-in periods. To calculate a global rate of assignation, individuals were arbitrarily deemed as assigned to a single genetic cluster when the proportion of ancestry in that cluster was greater than 0.8 . The ideal $K$ value was the one with the highest $\operatorname{Ln} \mathrm{P}(\mathrm{D})$ values as described by Evanno et al. (2005).

\section{RESULTS}

\section{Morphological variability}

From the 22 morphological traits measured in the FS plants, we classified 16 as qualitative and six as quantitative. Five qualitative traits showed three or more classes (Table 3), and all quantitative traits exhibited high variation coefficients (i.e. shaft diameter to the breast height and commercial height with values up $50 \%$ ). The germplasm had the following traits: straight shaft (66\%); round, irregular top shape $(50 \%)$; and branch insertion angle from $0^{\circ}$ to $30^{\circ}(86 \%)$. However, quantitative descriptors depend on location of each tree within forest areas, and they can be significantly influenced by environmental conditions. PCA explained $86.7 \%$ of total variability with the former three principal components (PC).

TABLE 3: Summary of qualitative traits of Triplaris guayaquilensis populations from Ecuador.

TABLA 3: Resumen de las características cualitativas de poblaciones de Triplaris guayaquilensis de Ecuador.

\begin{tabular}{lc}
\hline Trait & Classes (frequencies) $^{\mathrm{a}}$ \\
\hline \multicolumn{2}{c}{ Shaft } \\
Shaft shape & $1(34), 2(19), 3(2)$ \\
Principal axis dominance & $1(32), 2(18), 3(5)$ \\
Branch insertion angle & $1(34), 2(20), 3(1)$ \\
Un-bark degree & $1(45), 2(10), 3(0)$ \\
\hline \multicolumn{2}{c}{ Crown } \\
\hline Crown diameter & $1(29), 2(25), 3(1)$ \\
Crown shape & $1(4), 2(27), 3(2), 4(22)$ \\
\hline \multicolumn{2}{c}{} \\
\hline Edge shape & $1(0), 2(0), 3(55)$ \\
Adaxial color & $1(55), 2(0)$ \\
Abaxial color & $1(0), 2(55)$ \\
Pubescence & $1(0), 2(55)$ \\
Leaf length & $1(53), 2(2), 3(0)$ \\
Leaf shape & $1(0), 2(55), 3(0)$ \\
Leaf width & $1(0), 2(55)$ \\
Leaf texture & $1(55), 2(0)$ \\
Venation pattern & $1(55), 2(0)$ \\
\hline
\end{tabular}

${ }^{a}$ Classes were described on Table 2. Numbers in brackets indicate the number of accessions per class. 
According to the PCA, four qualitative (straight shape, type of leaf edge, leaf width and leaf pubescence) and four quantitative (commercial tree height, basal area, commercial volume and total volume) traits were the most explicative traits in FS. The most explicative traits corresponded to straight and trunk descriptors and all of the traits were positively associated with morphological variability in FS germplasm (Table 4). Using the data from the two major PCs (Figure 1), the FS populations were dispersed into four quadrants where quadrant I included individuals from Ventanas, and it had high values of commercial height, basal area, commercial volume and total volume but low values of straight shape, bifurcation height, principal axis dominance and total height. Quadrant II included plants from La Guayas and Quevedo, and it had high values of straight shape, bifurcation height, principal axis dominance, total height, commercial height, basal area, commercial and total volume, which are all desirable traits for commercial exploitation of FS. Quadrant III included trees from Patricia Pilar with high values of straight shape, bifurcation height, principal axis dominance, type of leaf edge, leaf width and total height, but had low values of commercial height, basal area, commercial volume and total volume. Finally, quadrant IV included plants from La Maná and Pichincha with low values for all previously described traits. Cluster analysis separated populations into two groups based on their geographical origin. Group I included populations from Quevedo, Ventanas and La Guayas (Central Coastals) with traits highly and positively correlated with wood production as described by PCA. Group II had populations with lower tree growth, which belonged to the Andean surrounding regions (Figure 2).

\section{AFLP analysis}

The four AFLP primer combinations produced 348 bands, and 276 of the bands were polymorphic (79 \%). The EcoRI+ACG/MseI+AAC combination showed the highest informativeness according to the diversity indexes calculated (data not shown). Populations from Central Coastals had the higes values of genetic diversity index (Quevedo $=0.78 \pm 0.13$; Ventanas $=0.77 \pm 0.13 ;$ La Guayas $=$ $0.69 \pm 0.14$ ), and populations with the lowest genetic diversity were from Andean surroundings (Pichincha $=0.58 \pm 0.06$; Patricia Pilar $=0.55 \pm 0.09$; la Mana $=0.52 \pm 0.08$ ). As the morphological analysis, AFLP analysis separated FS populations based on geographical origin with high levels of robustness. One group included populations from the Andean surroundings with low genetic diversity (DI $=0.55 \pm 0.03$ ). The other three populations (Quevedo, La Guayas and Ventanas) belonging to the Central Coastal region had high genetic diversity (DI $=0.74 \pm 0.05)$ (Figure 3$)$. AMOVA indicated significant differences among macro-sites and populations as well as within populations. The highest proportion of molecular variance (46\%) was found

TABELA 4: Eigenvectors of most descriptive traits of Triplaris guayaquilensis from Ecuador as indicated the Principal Component Analysis of morphological data.

TABLE 4: Vectores característicos de las características más descriptivas de Triplaris guayaquilensis de Ecuador de acuerdo con el Análisis de Componentes Principales de datos morfológicos.

\begin{tabular}{lccc}
\hline Traits & \multicolumn{3}{c}{ Principal Component } \\
\cline { 2 - 4 } & $1^{\text {a }}$ & 2 & 3 \\
\hline Shaft shape & $0.90^{*}$ & -0.20 & 0.30 \\
Height of bifurcation & $0.84^{*}$ & -0.02 & 0.21 \\
Principal axis dominance & $0.87^{*}$ & -0.27 & 0.22 \\
Branch insertion angle & 0.51 & -0.11 & 0.20 \\
Un-bark degree & -0.44 & 0.29 & 0.05 \\
Crown diameter & 0.47 & -0.25 & -0.28 \\
Crown shape & -0.58 & 0.51 & 0.48 \\
Edge shape & $0.88^{*}$ & 0.16 & -0.19 \\
Adaxial color & 0.13 & 0.13 & 0.20 \\
Abaxial color & 0.18 & 0.44 & -0.28 \\
Pubescence & $0.87^{*}$ & -0.41 & 0.05 \\
Leaf length & $0.70^{*}$ & -0.14 & 0.01 \\
Leaf shape & 0.10 & -0.07 & $0.95^{*}$ \\
Leaf width & $0.90^{*}$ & 0.16 & -0.19 \\
Leaf texture & 0.65 & -0.50 & 0.16 \\
Venation pattern & 0.34 & -0.32 & 0.16 \\
Shaft diameter to the breast & -0.13 & 0.92 & -0.02 \\
height & & & \\
Total height & $0.85^{*}$ & 0.36 & -0.22 \\
Commercial height & -0.34 & $0.87^{*}$ & -0.17 \\
Trunk base area & 0.01 & $0.98^{*}$ & 0.01 \\
Shaft total volume & 0.02 & $0.98^{*}$ & 0.01 \\
Shaft commercial volume & 0.08 & $0.98^{*}$ & 0.00 \\
Total explained variance $(\%)$ & 52.70 & 24.49 & 9.52 \\
Accumulated variance $(\%)$ & 52.70 & 77.19 & 86.71 \\
\hline
\end{tabular}

a Asterisks (*) indicate the most descriptive traits $(\mathrm{p}<0.01)$. 


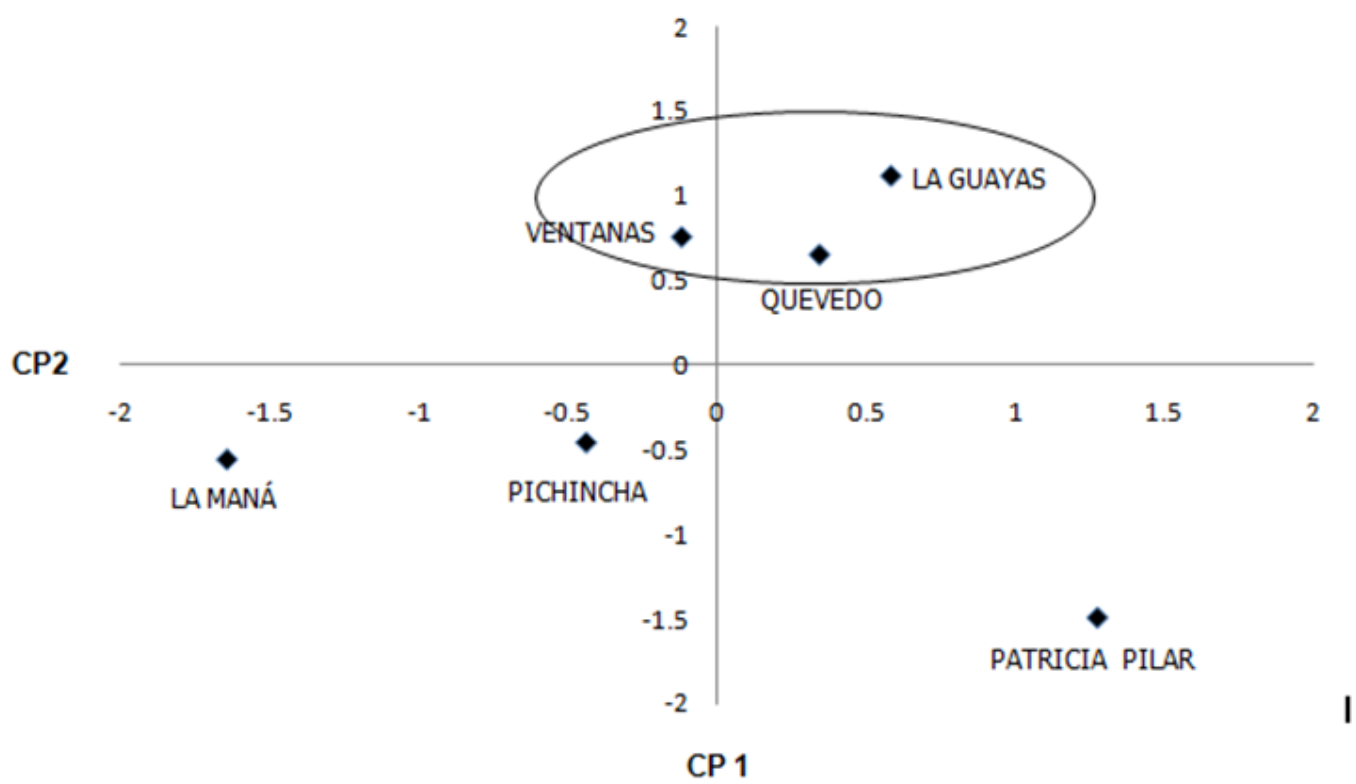

FIGURE 1: Dispersion of Triplaris guayaquilensis populations from Ecuador based on the data of two major principal components of PCA of morphological data.

FIGURA 1: Dispersión de las poblaciones de Triplaris guayaquilensis de Ecuador con base en datos delos dos principales componentes del ACP de datos morfológicos.

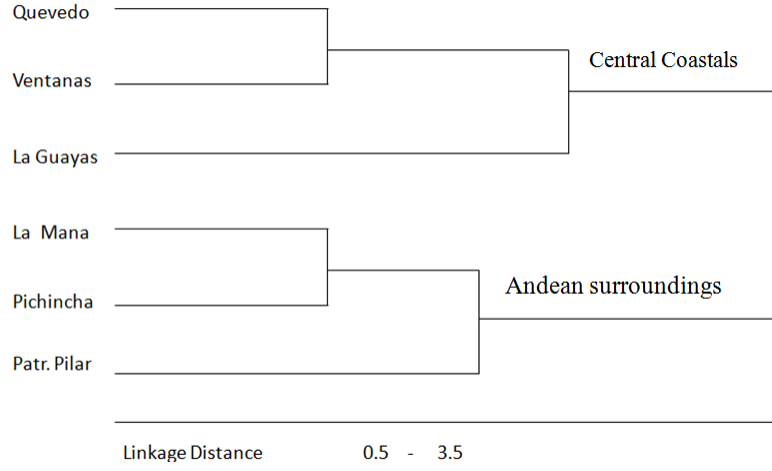

FIGURE 2: Dendrogram of Triplaris guayaquilensis populations from Ecuador by using morphological data.

FIGURA 2: Dendrograma de poblaciones de Triplaris guayaquilensis de Ecuador con base en datos morfológicos.

within populations, and the lowest proportion of molecular variance $(25 \%)$ was found among populations (Table 5). The genetic differentiation index $\left(\mathrm{F}_{\mathrm{ST}}\right)$ was 0.74 indicating high differentiation among all hierarchies analyzed. As mentioned above in Materials and Methods, the population structure was determined with the software STRUCTURE v. 2.3.1 (Pritchard et al., 2000) without pre- identification of individuals within any particular group.

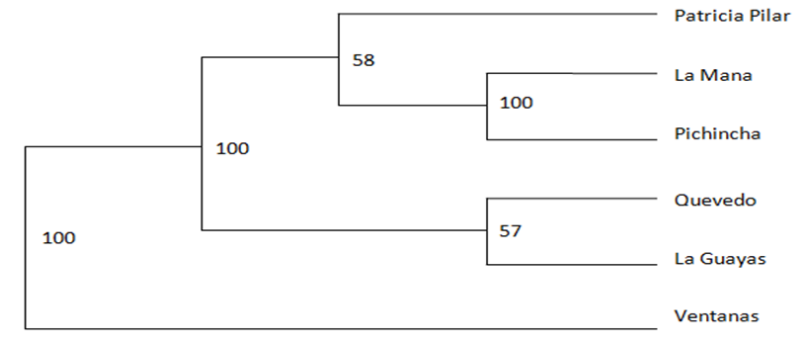

FIGURE 3: Dendrogram of Triplaris guayaquilensis populations from Ecuador based on AFLP data. Numbers of each node indicates repeatability values (\%) from bootstrap analysis.

FIGURA 3: Dendrograma de poblaciones de Triplaris guayaquilensis de Ecuador con base en datos AFLP. Los números en cada nodo indican los valores de repetibilidad (\%) del análisis de robustez.

Therefore, the program itself assigned genotypes to populations. Furthermore, the optimum number of populations was decided on with the $\Delta K$-based test of Evano et al. (2005). The $\Delta K$ value constantly decreased from $2351(K=2)$ to $24(K=6)$, the highest peaks were found for $K=2$ (2351), $K=3$ (623) (data not shown) and then both were used in this 
TABLE 5: AMOVA of six Triplaris guayaquilensis populations from Ecuador by using AFLP data.

TABLA 5: AMOVA de seis poblaciones de Triplaris guayaquilensis de Ecuador con base en datos AFLP.

\begin{tabular}{lcccc}
\hline $\begin{array}{l}\text { Source of } \\
\text { variation }\end{array}$ & d.f. & $\begin{array}{c}\text { Squared } \\
\text { means }\end{array}$ & $\begin{array}{c}\text { Explained } \\
\text { variance (\%) }\end{array}$ & P \\
\hline $\begin{array}{l}\text { Among macro } \\
\text { sites }\end{array}$ & 1 & 938.96 & 27.65 & 0.0133 \\
$\begin{array}{l}\text { Among } \\
\text { populations }\end{array}$ & 4 & 216.62 & 25.52 & $<0.0001$ \\
$\begin{array}{l}\text { Within } \\
\text { populations }\end{array}$ & 46 & 34.6 & 46.8 & $<0.0001$ \\
Total & 54 & 62.87 & 100 & \\
\hline
\end{tabular}

study because of our interest in subdividing the full population into groups. For $K=2$ the FS populations were divided into two groups; two populations from Central Coastals region and the other four the Andean region (three) and one from Central Coastals (La Guayas). For greater $K$ values, genetic fragmentation of populations by origins was evident since for $K=5$ four groups were performed: one including the populations from Quevedo and Ventanas and other from La Guayas (Coastals) as well as one third group from La Mana and Pichincha and other from Patricia Pilar (Andean surroundings) (Figure 4).

\section{DISCUSSION}

The Fernan Sanchez (Triplaris guayaquilensis) is one of the native forest species of Ecuador, and it is currently endangered due to several factors including indiscriminate fell, selective exploitation, no management plans and no conservation of genetic resources. Despite the negative factors, our results emphasize the great genetic variability of FS throughout Ecuador. PCA was highly explicative of morphological variability of Triplaris guayaquilensis $(>85 \%$ within the three former PCs), which has previously been described by LI et al. (2008) for Paramichelia baillonii and by MIRANDA et al. (2000) for P. halepensis. The following traits were the most explicative traits: six traits from the tree shaft, two traits from the tree crown and four traits from the leaves. All of these traits positively associated with genetic variability of FS. Further studies in FS should take into account the most explicative traits as indicated below.

Based on the values for the two major PCs, Triplaris guayaquilensis populations were grouped according to common morphological traits. Populations from Ventanas, La Guayas and Quevedo were in quadrants I and II. All of them had high tree growth and wood production due to their location in geographical regions with climatic conditions for tree growth. The other FS populations had low values for tree growth and wood production due to their location near the Andes where weather conditions are not favorable for reproduction and tree growth. LI et al. (2008) used 45 descriptors to analyze morphological variations in $P$. baillonii and they reported that traits, such as length of wood fibers or wood relative density, clearly grouped similar populations. Our morphological descriptors were powerful and reliable enough to group and to discriminate T. guayaquilensis based on previous geographical origin data. In addition, the descriptors were advantageous because of the easy registering method.

The polymorphism registered for Triplaris guayaquilensis $(79.5 \%)$ was similar to the polymorphism previously reported by CAVERS et al. (2003) in C. odorata (84 \%) using AFLPs but was lower than the values reported by GILLIES et al. (1997) using RAPDs and DE LA TORRE et al. (2008) using AFLPs $(93.8 \%$ and $98.8 \%$, respectively) in C. odorata. Moreover, the polymorphism registered for $T$. guayaquilensis was higher than the polymorphism reported by DÍAZ et al. (2001) $(43.8 \%)$ in P. oocarpa. Our data demonstrated the high efficiency of AFLPs to detect polymorphisms, to produce high numbers of amplified products per reaction and their efficiency of AFLPs to detect genetic variations in forest species, such as FS. The genetic diversity index values of FS were lower than the values reported for $S$. parahybum in Ecuador (CANCHIGNIA-MARTÍNEZ et al., 2007) but similar to values found for Tectona grandis (teak) (NIETO-RODRÍGUEZ, 2010).

While the AFLP marker system was only capable of detecting and clearly differentiating native Ecuadorian $S$. parahybum ecotypes from commercial or foreign populations (CANCHIGNIAMARTÍNEZ et al., 2007), molecular markers in this study were able to propose a probable site of dispersion of Triplaris guyaquilensis based on the criteria previously described by RIVERA-OCASIO et al. (2002). Coastal region (Quevedo and Ventanas) and FS populations were dispersed and then colonized throughout Ecuador's territory. RIVERA-OCASIO et al. (2002) analyzed Pterocarpus officinalis populations from South America, Central America and 


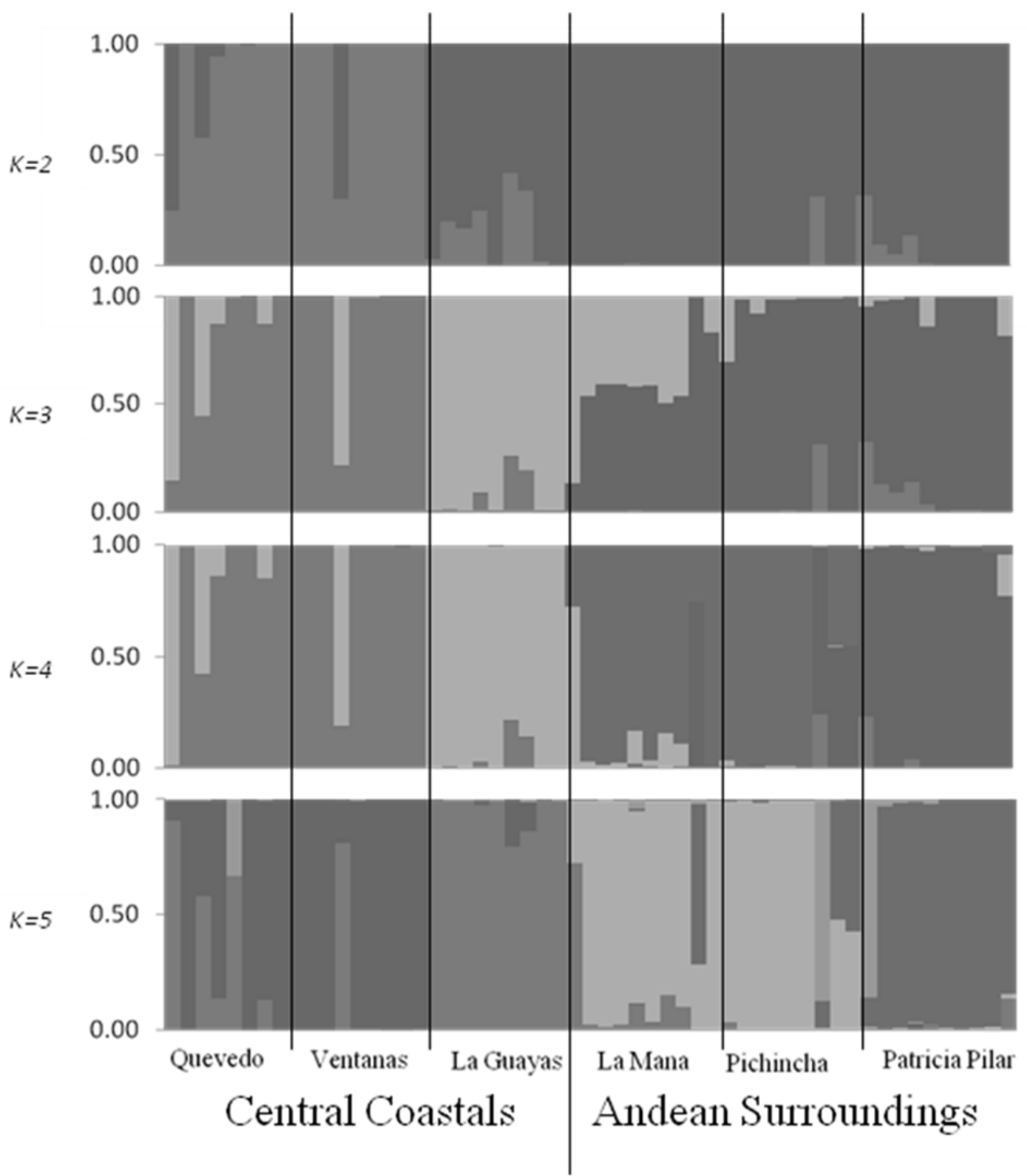

FIGURE 4: Estimated Triplaris guayaquilensis genetic structure. Each tree is represented by a thin vertical line which is partitioned into $K$ segments representing the individual estimated membership fractions in $K$ clusters. Black lines separated individuals from different populations labeled by population and origin.

FIGURA 4: Estructura genetic estimada en Triplaris guayaquilensis. Cada árbol se representa por una línea vertical que se particiona en $K$ segmentos que representan las fracciones de membresía estimada de cada individuo en los $K$ conglomerados. Las líneas negras separan los individuos de las diferentes poblaciones etiquetadas por población y origen. 
the Caribbean. The highest genetic diversity values were found in continental populations (Venezuela) and decreased in the Caribbean islands. The variation in genetic diversity values suggested an introduction site of any exotic species to a new environment and the most probable dissemination pattern. Thus, genetic variability found in FS from Ecuador reflects the degree of perturbation and fragmentation due to anthropic activity, which is greater near urban regions and may cause genetic erosion of the species (DE LA TORRE et al., 2008).

The germplasm of Triplaris guayaquilensis was divided into two groups for $K=2$, one group included two populations from Central Coastals region and the other four ones from the Andean region (three) and Central Coastals (La Guayas). For greater $K$ values genetic fragmentation of populations by origins, it was evident since for $K=5$ four groups were performed: one including the populations from Quevedo and Ventanas and other from La Guayas (Coastals) as well as one third group from La Mana and Pichincha and another one from Patricia Pilar (Andean surroundings). Data suggested a genetic mixture among populations and probable fragmentation for larger $K$ values. Bayesian cluster analysis is based on the statistical models that use allele frequencies of each locus (PRITCHARD et al., 2000; BONIN et al., 2007), and the statistical methods that use genetic distances are based on the presence or absence of each locus (similarity or dissimilarity among individuals). Our data suggest a constant and effective genetic recombination or genetic flow among and within FS populations with a clear tendency towards genetic differentiation.

\section{CONCLUSIONS}

The morphologic analysis of Triplaris guayaquilensis indicated that populations can be clearly separated by using both qualitative (straight shape, type of leaf edge, leaf width and leaf pubescence) and quantitative (commercial tree height, basal area, commercial volume and total volume) traits. Populations from Central Coastals showed morphologic traits highly and positively correlated with wood production and they can be used for Fernan Sanchez genetic improvement or direct propagation and further re-planting of eroded or degraded areas.

Genetic analysis indicated the genetic fragmentation of populations based on each origin suggesting the constant and effective genetic recom- bination or genetic flow among and within Fernan Sanchez populations with a clear tendency towards genetic differentiation.

\section{ACKNOWLEDGEMENTS}

Authors are grateful to 'Consejo Nacional de Ciencia y Tecnología' (CONACYT) of México, the 'Secretaria Nacional de Ciencia y Tecnología' (SENACYT) of Ecuador, the 'Universidad Técnica Estatal de Quevedo', Ecuador, the 'Instituto Politécnico Nacional' (IPN), the 'Centro de Investigación en Ciencia Aplicada y Tecnología Avanzada Unidad Altamira' (CICATA-IPN), the 'Centro de Biotecnología Genómica' (CBG-IPN), FOMIX-Gobierno del Estado de Tamaulipas, and the 'Programa Institucional para la Formación de Investigadores' (PIFI-IPN) for financial support to the experimental work as well as the Ph.D. program in plant biotechnology to the first author. Publication of this paper was defrayed by the 'Fondo Mixto de Fomento a la Investigación Científica y Tecnológica', CONACYT-Gobierno del Estado de Tamaulipas. The second and third authors are S. N. I., COFAA-IPN and EDI-IPN scholars.

\section{REFERENCES}

AGUIRRE, Z.; LARS, P. Composición florística y estado de conservación de los bosques secos del surOccidente del Ecuador. Lyonia, Honolulu, v. 8, n. 1, p. 41-67. Jul. 2005.

BONIN, A. et al. Statistical analysis of amplified fragment length polymorphism data: a toolbox for molecular ecologists and evolutionists. Molecular Ecology, Chichester, v. 16, n. 18, p. 3737-3758. Sept. 2007.

CANCHIGNIA-MARTÍNEZ, H. F. et al. Genetic relationships among Schizolobium parahybum (Vell.) Blake (Leguminosae) ecotypes from Ecuador and other countries. Silvae Genetica, Frankfurt, v. 56 n. 5, p. 214-221, Nov. 2007.

CAÑADAS, L. C.; ESTRADA, W. A. EcuadorMapa Bioclimático. Ministerio de Agricultura y Ganadería. Programa Nacional de Regionalización Agraria Departamento de Ecología. Quito, Ecuador. 1986

CAVERS, S. et al. A combination of molecular markers identifies evolutionarily significant units in Cedrella odorata L. (Meliaceae) in Costa Rica. Conservation Genetics, Dordrecht, v. 4, n. 5, p. 571-580. Sept. 2003. 
DE LA TORRE, A. et al. Genetic (AFLP) diversity of nine Cedrela odorata populations in Madre de Dios, southern Peruvian Amazon. Forest Ecology and Management, Amsterdam, v. 255, n. 2, p. 334-339, March 2008.

DÍAZ, V. et al. Random amplified polymorphic DNA and amplified fragment length polymorphism assessment of genetic varation in Nicaragua populations of Pinus oocarpa. Molecular Ecology, Chichester, v. 10, n. 11, p. 2593-2603, Nov. 2001.

EVANNO, G. et al. Detecting the number of clusters of individuals using the software STRUCTURE: A simulation study. Molecular Ecology, Chichester, v. 14, n. 8, p. 2611-2620, Aug. 2005.

EXCOFFIER, L. et al. Arlequin ver. 3.0: An integrated software package for population genetics data analysis. Evolutionary Bioinformatics Online, v. 1, n. 1, p. 47-50, Feb. 2005.

GILLIES, A. et al. Genetic variation in Costa Rican populations of Spanish cedar. Molecular Ecology, Chichester, v. 6, n. 12, p. 1133-1145, Dec. 1997.

HAIR, J. F. et al. Multivariate Data Analysis with Readings. Fourth edition. Prentice-Hall, Englewood Cliffs, 1995. 708 p.

HAMPL, V. et al. Concordance between genetic relatedness and phenotypic similarities of Trichomonas sp. BMC Evolution Biology, London, v. 1, p. 11, Nov. 2001

HOLDRIGE, L.R. Ecología Basada en Zonas de Vida. Instituto Interamericano para la Cooperación en la Agricultura. San José. 1982. 216 p.

HUFF, D. et al. RAPD variation whitin and among natural populations of outcrossing buffalo grass [Buchoe dayloides (Nutt) Engelm]. Theoretical and Applied Genetics, Heidelberg, v. 86, n. 8, p. 927-934, Sept. 1993.

JORGENSEN, P.; LEÓN, S. Y. Catalogue of the Vascular Plants of Ecuador. Missouri Botanical Garden. Saint Louis, 1999.1181 p.

LEOPOLD, H. et al. Descriptores Morfológicos de Especies Forestales Maderables de Sud América. Consejo Nacional Forestal (CONAF). Santiago, 2001.

LI, F. et al. RAPD and morphological diversity among four populations of the tropical tree species Paramichelia baillonii (Pierre) Hu in China. Forest Ecology and Management, Amsterdam, v. 255, n. 5/6, p. 1793-1801, Ap.1 2008.

LITTLE, E. L.; DIXON, R. G. Árboles Comunes de la Provincia de Esmeraldas, Ecuador. United
Nations Development Program and Food and Agriculture Organization. Rome, 1969. 536 p.

LOWE, A. J. et al. Fine-scale genetic structure and gene flow within Costa Rican populations of mahogany (Swietenia macrophylla). Heredity, Sheffield, v. 90, n. 3, p. 268-275, March 2003.

MIRANDA, R. et al. La mejora genética del 'Pino Carrasco' (Pinus halepensis Mill). Cuadernos de la Sociedad Española de Ciencias Forestales, Madrid, v. 10, n. 1, p. 19-27, 2000.

NAMKOOG, G.; KOSHY, M. Application of Genetic Markers to Forest Tree Species. Draft report to IPGRI of the project 'Developing DecisionMaking Strategies on Priorities for conservation and Use of Forest Genetic Resources' IPGRI. Rome, 2001. $26 \mathrm{p}$.

NEI, M.; KUMAR, S. Molecular Evolution and Phylogenetics. Oxford University Press, Oxford, 2000. 333 p.

NEI, M.; LI, W.H. Mathematical model for studying genetic variation in terms of restriction endonucleases. Proceedings of the National Academy of Sciences, USA, Washington, v. 76, n. 10, p. 5269-5273. Oct. 1979.

NIETO-RODRÍGUEZ, J. E. Diversidad Genética de 12 Ecotipos de Teca (Tectona grandis L.) del Litoral Ecuatoriano. M.Sc. Thesis. Universidad Internacional de Andalucía. Huelva, Feb. 2010. $50 \mathrm{p}$.

ORDÓÑEZ, O. et al. Las Fuentes Semilleras y Semillas Forestales Nativas de Loja y Cañar: Participación Social en el Manejo. Fundación Ecológica 'Arco Iris'- ASOCAM. Loja, 2005. 80 p. PAGE, R. D. TreeView. Division of Environmental and Evolutionary Biology, Institute of Biomedical and Life Sciences. University of Glasgow. Glasgow, Scotland. Available in: http://taxonomy.zoology.gla. ac.uk/rod/treeview.html, 2000.

POWELL, W. et al. The comparison of RFLP, RAPD, AFLP and SSR (microsatellites) marker for germoplasm analysis. Molecular Breeding, Heidelberg, v. 2, n. 3, p. 225-238, Sept. 1996.

PRITCHARD, J. et al. Inference of population structure using multilocus genotype data. Genetics, Bethesda, v. 155, n. 2, p. 945-959. June 2000

RIVERA-OCASIO, E. et al. Patterns of genetic diversity and biogeographical history of the tropical wetland tree, Pterocarpus officinales (Jacq.), in the Caribbean basin. Molecular Ecology, Chichester, v. 11, n. 4, p. 675-683, Apr. 2002.

SCHNEIDER, S. et al. Arlequin version 1.1: A software for population genetic data analysis. 
Genetics and Biometry Laboratory. University of Geneva, Geneva, 1997.

STATSOFT Inc. STATISTICA for Windows

[Computer program manual]. Version 7.0. Tulsa, 2004.

THOMAS, B. R. et al. Effects of reforestation methods on genetic diversity of lodge pole pine: an assessment using microsatellite and randomly amplified polymorphic DNA markers. Theoretical and Applied Genetics, Heidelberg, v. 98, n. 5, p.
793-801, Apr. 1999.

VALLEJO, L.M.; MALDONADO, E.C. Mapa General de Suelos del Ecuador. Sociedad Ecuatoriana de la Ciencia del Suelo. Quito, 1987. VALVERDE, F. Estado Actual de la Vegetación Natural de la Cordillera Chongon-Colonche. Guayaquil, Universidad de Guayaquil, 1991, 387 p. VOS, P. et al. AFLP: A new technique for DNA fingerprinting. Nucleic Acids Research, Oxford, v. 23, n. 21, p. 4407-4414, Nov. 1995. 